\title{
Brasetto hybrid winter rye
}

\author{
P. Wilde, B. Schmiedchen, J. Menzel, A. Gordillo, and D. Brian Fowler
}

\begin{abstract}
Brasetto is one of the first two hybrid winter (fall) rye (Secale cereale L.) cultivars to be registered for production in Canada. In registration trials, its grain yield was $42 \%$ higher than the mean of the check entries and $23 \%$ higher than the highest yielding reference cultivar, Hazlet. It has a very high falling number, which is of special interest in the food market. Except for lower grain protein content and a slightly higher ergot [Claviceps purpurea (Fr.) Tul.] level, the rest of its measured agronomic and quality characters have been better than or within the range of the Fall Rye Co-operative Registration Trial check cultivars in Canada. Its expected end use will be primarily for food and feed grain.
\end{abstract}

Key words: Secale cereale L., cultivar description, hybrid, rye (winter), grain yield, falling number.

Résumé : Brasetto est l'une des deux premières variétés de seigle d'hiver (automne) (Secale cereale L.) hybrides à être homologuée en vue de sa culture au Canada. Lors des essais d'homologation, son rendement grainier a dépassé le rendement moyen des cultivars témoins de $42 \%$ et celui d'Hazlet, variété de référence au rendement le plus élevé, de $23 \%$. Brasetto a un indice de chute très élevé, ce qui pourrait intéresser le marché de l'alimentation. Exception faite d'un grain moins riche en protéines et d'une sensibilité légèrement plus grande à l'ergot [Claviceps purpurea (Fr.) Tul.], les autres paramètres agronomiques et qualitatifs de Brasetto sont supérieurs ou équivalents à ceux des cultivars témoins utilisés dans les essais d'homologation coopératifs sur le seigle d'automne au Canada. On s'attend à ce que cette nouvelle variété serve principalement de céréale vivrière et fourragère. [Traduit par la Rédaction]

Mots-clés : Secale cereale L., description de cultivar, hybride, seigle (hiver), rendement grainier, indice de chute.

\section{Introduction}

Brasetto hybrid winter rye was developed by KWS LOCHOW GMBH, Bergen, Germany. The Variety Registration Office, Plant Production Division, Canadian Food Inspection Agency, issued registration no. I-374 for Brasetto on 20 May 2015.

\section{Pedigree and Breeding Methods}

Brasetto is a four-way hybrid from the topcross of a cytoplasmic male-sterile $(\mathrm{CMS})$ single $(\mathrm{N} 24-\mathrm{P} \times \mathrm{N} 26-\mathrm{N})$ cross with a restorer synthetic (LSR80). The restorer synthetic is derived from the cross of two lines.

The parents of the first component of the CMS single cross, N24, were crossed in 1993 . $S_{2}$ lines were developed through self-pollination and visually selected in observation rows in Germany in two locations in 1995 for relevant agronomic traits including standability, seed set, and resistance to diseases. In case of incidence, the following diseases were selected visually under natural infection: resistance to foot rot, frequently caused by a complex of Helgardia herpotrichoides (Fron) Crous \& W. Gams, Oculimacula acuformis (Boer., Pietr. \& Hamers) (syn. Pseudocercosporella herpotrichoides var. herpotrichoides (Fron) Deigh.; P. herpotrichoides var. acuformis Niren.), Microdochium nivale (Fr.) Samuels \& I.C. Hallett, Fusarium spp., powdery mildew (Blumeria graminis f. sp. secalis), leaf rust (Puccinia recondita Dietel \& Holw.), stem rust (P. graminis f. sp. secalis), leaf blotch [Rhynchosporium secalis (Oudem.) Davis], ergot [Claviceps purpurea (Fr.) Tul.], and Fusarium head blight caused by M. nivale and various Fusarium species.

In addition, $S_{2}$ lines were selected for thousand-kernel weight (TKW) and Hagberg falling number based on a sample of harvested seed from each observation row of lines preselected in the field for agronomic traits. $S_{2}$ lines were self-pollinated to the $S_{6}$ generation. In parallel to this line development procedure, N24 was transferred into CMS-inducing cytoplasm via backcrossing to

Received 30 November 2016. Accepted 1 May 2017.

P. Wilde, B. Schmiedchen, J. Menzel, and A. Gordillo. KWS LOCHOW GMBH, Ferdinand-von-Lochow-Straße 5, 29303 Bergen, Germany. D. Brian Fowler. Department of Plant Sciences, University of Saskatchewan, 51 Campus Drive, Saskatoon, SK S7N 5A8, Canada.

Corresponding author: Andrés Gordillo (email: andres.gordillo@kws.com).

Copyright remains with the author(s) or their institution(s). Permission for reuse (free in most cases) can be obtained from RightsLink. 
produce the near-isogenic CMS analogue of N24 corresponding to N24-P. The $S_{3}$ to $S_{6}$ lines were visually selected in observation rows in two locations between 1996 and 1999, respectively, using the methodology described above for the selection of $S_{2}$ lines. First testcrosses of selected lines were produced with testers from the opposite gene pool in 1996 and selected in field (alpha design) trials with two replicates across eight locations in Germany in 1997. Selection criteria were general combining ability (GCA) for yield, TKW, standability, and resistance to the diseases mentioned previously. In 1998, a second GCA test was carried out using the same experimental design across five representative rye growing locations in Germany and five locations in Poland. Testcross seed was produced between 1998 and 2002 for selection in GCA trials across six locations in Germany and six locations in Poland between 1999 and 2003, respectively. The selection scheme of line $\mathrm{N} 26-\mathrm{N}$ was the same as for line N24, but with two years of time lag.

The parents of the first line (component) of the restorer synthetic LSR80 were crossed in 1993. $S_{2}$ lines were developed through self-pollination and selected in observation rows in Germany in two locations in 1999 and 2002, respectively. The same selection methodology was used as described above for the $S_{2}$ lines in the seed parent pool. Testcrosses of selected lines were produced with testers from the opposite gene pool in 2000. In 2001, the best lines were selected in field (alpha design) trials with two replicates across three locations in Germany and one location in Poland for GCA for yield, TKW, standability, and resistance to the diseases mentioned previously. A second GCA test was carried out in 2002 across five locations in Germany and five locations in Poland. Testcross seed was produced again in 2002 and 2003 for selection in GCA trials across six locations in Germany and six locations in Poland in 2003 and 2004 , respectively. The selection scheme of the second parental line of the restorer synthetic LSR80 was the same as for the first parental line, with three years of time lag. The restorer synthetic LSR80 was produced via crossing by hand-emasculation of the two parental lines, followed by open pollination under isolation.

In 2003, seed of line N24-P and N26-N was increased. The CMS single cross $(\mathrm{N} 24-\mathrm{P} \times \mathrm{N} 26-\mathrm{N})$ was produced in 2004. In the same year, the restorer synthetic LSR80 was increased. In 2005, first hybrid trial seed from the cross of the CMS single $(\mathrm{N} 24-\mathrm{P} \times \mathrm{N} 26-\mathrm{N})$ and the restorer synthetic LSR80 was harvested. This hybrid was tested in official trials in Germany between 2005-2006 and 2007-2008 and registered in Germany in 2009. Brasetto was tested in 2010-2011 in one location in Estonia and two locations in Russia (near Moscow and Ufa). This hybrid was then tested in the 2011-2012, 2012-2013, and 2013-2014 Fall Rye Co-operative Registration Trial in Canada across six locations in Alberta, four locations in Saskatchewan, and three locations in Manitoba under the entry code RT209.
The Fall Rye Co-operative Registration Trial followed the operating procedures of the Prairie Recommending Committee for Wheat, Rye and Triticale (PRCWRT, PRCWRT 2015). In short, the trials were arranged in a randomized complete block or lattice design with three replicates. No seed treatments or fungicides were permitted in the trial. Agronomic data collected from each plot at each location include winter survival, heading date, plant height, lodging, and maturity as described in appendix $C$ of the PRCWRT operating procedures (PRCWRT 2015). Grain yield data were accepted if the coefficient of variation $(\mathrm{CV})$ was less than $12 \%$. Grain yield data were also accepted if the CV was in the range of $12 \%-15 \%$ and the appropriate $F$ test for genotypes was significant $(P<0.05)$ or a CV in the range of $15 \%-20 \%$ if the appropriate $F$ test of genotypes was highly significant $(P<0.01)$. Leaf spot disease scores on a 1-9 scale were assessed based on the proportion of leaf area with lesions in the field at one, two, and one trial location in 2012, 2013, and 2014 , respectively. Leaf spot is usually associated with leaf rust and leaf blotch affection. In the present Fall Rye Co-operative Registration Trial, an analysis to determine the pathogens underlying leaf spot scores was not made. Therefore, leaf spot data are not presented herein. Grain quality traits and incidence of ergot were measured on a composite sample of each variety from each location. Grain quality and disease data collected included test weight, TKW [for details refer to appendix $C$ of the PRCWRT operating procedures (PRCWRT 2015)], ergot (\%), protein (\%), and Hagberg falling number. For determination of ergot, sclerotia were separated from a 500 g grain sample and weighed to determine the percentage of ergot sclerotia. For determination of protein, whole grain was analysed using standard calibration curves developed for near-infrared spectrometry. Hagberg falling number was determined on an approximately $7 \mathrm{~g}$ sample of clean, ergot-free ground rye by AACC method 56-81.03.

In April of 2014, Brasetto received support for interim registration. In April of 2015, it received support for full registration from PRCWRT.

\section{Performance}

The grain yield of Brasetto was $42 \%$ higher than the mean of the check entries in the 2011-2014 Fall Rye Cooperative Registration Trial (Table 1). It had a 23 percent yield advantage over the highest yielding check cultivar, Hazlet (McLeod and Gan 2008), which was the dominant commercial rye cultivar grown in western Canada. The heading date, maturity, height, lodging (Table 2), TKW, and test weight (Table 3) of Brasetto fell within the range of the check cultivars. Brasetto had shorter, stronger straw than Hazlet and Prima (McLeod et al. 1985), while Brasetto, Hazlet, and Prima were taller and more prone to lodging than AC Rifle 
Table 1. Grain yield $\left(\mathrm{kg} \mathrm{ha}^{-1}\right)$ of Brasetto compared with AC Rifle, Hazlet, and Prima based on the 2011-2012, 2012-2013, and 2013-2014 Fall Rye Cooperative Registration Trials.

\begin{tabular}{|c|c|c|c|c|c|}
\hline \multirow[b]{2}{*}{ Cultivar } & \multicolumn{3}{|l|}{ Region } & \multirow[b]{2}{*}{$\operatorname{Mean}^{a}$} & \multirow[b]{2}{*}{$\%$ of checks } \\
\hline & Alberta & Saskatchewan & Manitoba & & \\
\hline Prima & 6079 & 5120 & 4408 & 5477 & 100 \\
\hline AC Rifle & 5354 & 3913 & 3961 & 4635 & 85 \\
\hline Hazlet & 7243 & 5776 & 4842 & 6341 & 116 \\
\hline Brasetto & 8766 & 7041 & 6405 & 7783 & 142 \\
\hline Grand mean & 7243 & 5745 & 5161 & 6385 & - \\
\hline Check mean & 6225 & 4936 & 4404 & 5484 & - \\
\hline $\operatorname{LSD}(0.05)^{b}$ & 570.7 & 669.0 & 633.4 & 208.2 & - \\
\hline $\mathrm{CV}(\%)^{c}$ & 10.4 & 12.9 & 9.2 & 11.0 & - \\
\hline No. of locations & 14 & 10 & 5 & 29 & - \\
\hline
\end{tabular}

Note: - , no value.

${ }^{a}$ Mean value is weighted by the number of tests within a zone. Alberta locations included Lethbridge, Morrin, Trochu, Olds, Lacombe, and Beaverlodge. Saskatchewan locations were Swift Current, Saskatoon, Indian Head, and Melfort. The Manitoba locations were Brandon, Carman, and Winnipeg.

${ }^{b}$ Least significant difference at a $5 \%$ level.

${ }^{c}$ Coefficient of variation.

Table 2. Agronomic performance of Brasetto compared with AC Rifle, Hazlet, and Prima based on the 2011-2012, 2012-2013, and 2013-2014 Fall Rye Cooperative Registration Trials.

\begin{tabular}{|c|c|c|c|c|c|}
\hline Cultivar & Heading $(\mathrm{d})^{a}$ & Maturity (d) ${ }^{a}$ & Height $(\mathrm{cm})$ & $\begin{array}{l}\text { Lodging } \\
\text { score }(1-9)^{b}\end{array}$ & $\begin{array}{l}\text { Winter } \\
\text { survival (\%) }\end{array}$ \\
\hline Prima & 161.4 & 218.7 & 121.2 & 3.4 & 80.3 \\
\hline AC Rifle & 164.3 & 219.1 & 89.3 & 1.6 & 76.6 \\
\hline Hazlet & 161.3 & 221.5 & 110.9 & 2.8 & 86.0 \\
\hline Brasetto & 161.3 & 221.4 & 100.1 & 2.4 & 87.7 \\
\hline Grand mean & 162.0 & 220.4 & 103.9 & 2.5 & 83.7 \\
\hline Check mean & 162.3 & 219.8 & 107.1 & 2.6 & 80.9 \\
\hline $\operatorname{LSD}(0.05)^{d}$ & 0.2 & 0.5 & 1.5 & 0.2 & 3.0 \\
\hline $\mathrm{CV}(\%)^{e}$ & 0.5 & 0.8 & 5.0 & 24.4 & 11.7 \\
\hline Locations & 29 & 30 & 30 & 16 & 28 \\
\hline
\end{tabular}

${ }^{a}$ d, days after 1 Jan.

${ }^{b}$ Recorded on a 1-9 scale, where 1 is bolt upright and 9 is completely prone, wherever significant lodging occurs.

${ }^{c}$ Estimated to nearest $5 \%$ after spring regrowth wherever there is winterkill.

${ }^{d}$ Least significant difference at a $5 \%$ level.

${ }^{e}$ Coefficient of variation.

(McLeod and Payne 1996). The winter survival of Brasetto was significantly better than Prima and AC Rifle and similar to Hazlet. Its level of ergot infection was higher than Prima and not significantly different from AC Rifle and Hazlet (Table 3). Brasetto had a very high falling number, which is of special interest in the food market. The protein concentration of Brasetto was lower than that of the check cultivars. However, its protein yield (grain yield $\times$ percent protein) was significantly higher $\left(710 \mathrm{~kg} \mathrm{ha}^{-1}\right)$ than both Prima $\left(546 \mathrm{~kg} \mathrm{ha}^{-1}\right)$ and AC Rifle $\left(470 \mathrm{~kg} \mathrm{ha}^{-1}\right)$ and similar to Hazlet $\left(649 \mathrm{~kg} \mathrm{ha}^{-1}\right)$.

\section{Other Characteristics \\ Plant}

Winter growth habit; coleoptile colour: reddish; flag leaf width narrow to medium; slightly waxy; leaf next to flag leaf short to medium length; culm upper internode pubescent.

Spikes

Horizontal to semi re-curved attitude; medium to high density; medium-long to long; slightly waxy, awned.

\section{Kernel}

Elongated-elliptical. 
Table 3. Leaf spot, ergot, test weight, thousand-kernel weight (TKW), Hagberg falling number, grain protein content, and yield of Brasetto compared with AC Rifle, Hazlet, and Prima based the 2011-2012, 2012-2013, and 2013-2014 Fall Rye Cooperative Registration Trials.

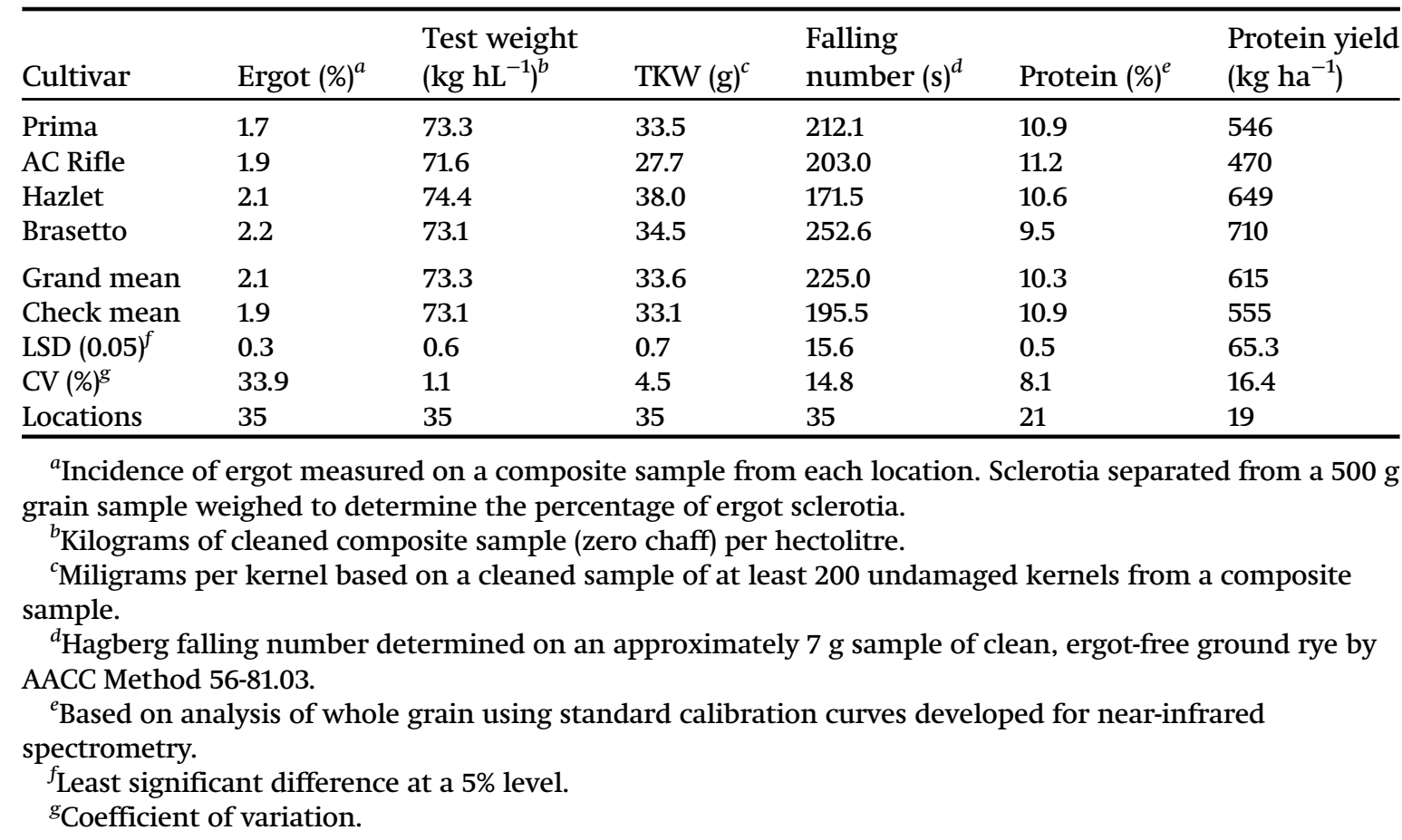

\section{Maintenance and Distribution of Pedigreed Seed}

Brasetto has been maintained as a topcross hybrid from a CMS single $(\mathrm{N} 24-\mathrm{P} \times \mathrm{N} 26-\mathrm{N})$ cross with a restorer synthetic (LSR80). Seed of this hybrid used in evaluation and selection trials was produced in isolated fields. Seed originating from these isolations has also been used to produce breeder seed. Breeder seed will be maintained by KWS LOCHOW GMBH, Ferdinand-von-LochowStraße 5, 29303, Bergen, Germany. Distribution and multiplication of pedigreed seed stocks are handled by FP Genetics, 426 McDonald Street, Regina, SK S4N 6E1, Canada.

\section{Acknowledgements}

The many contributions of the coordinator, Dr. J. Larsen, and the co-operators who provided the database of the Fall Rye Co-operative Registration Trial are gratefully acknowledged. This project was made possible by grants from Ducks Unlimited Canada and Genome Prairie.

\section{References}

McLeod, J.G., McBean, D.S., Payne, J.F., and Buzinski, S.R. 1985. Prima winter rye. Can. J. Plant Sci. 65: 447-448. doi:10.4141/ cjps85-061.

Mcleod, J.G., and Payne, J.F. 1996. AC Rifle winter rye. Can. J. Plant Sci. 76: 143-144. doi:10.4141/cjps96-026.

McLeod, J.G., and Gan, Y. 2008. Hazlet winter rye. Can. J. Plant Sci. 88: 527-529. doi:10.4141/CJPS07171.

PRCWRT. 2015. Operating procedures. Prairie Grain Recommending Committee for Wheat, Rye and Triticale. [Online] Prairie Recommending Committee for Wheat, Rye and Triticale, Lethbridge, AB. Available: http://www.pgdc. ca/pdfs/wrt/Proposed\%20PRCWRT\%200PS\%20-\%20FINAL\% 20DRAFT\%20-\%2027\%20Nov\%202013\%20Updated\%205\% 20December\%202015.pdf. 